IRSH 59 (2014), pp. 443-47I doi:I0.1017/S00208590I 4000467

(C) 2014 Internationaal Instituut voor Sociale Geschiedenis

\title{
Hostels for Jobless Workers in Interwar Yugoslavia (I92I-I94I)*
}

\author{
STEFANO PETRUNGARO \\ Department of History, \\ Institute of East and Southeast European Studies \\ Landshuter Straße 4, 93047 Regensburg, Germany \\ E-mail: petrungaro@ios-regensburg.de
}

\begin{abstract}
AвSTRACT: This article analyses the establishment of a network of hostels for unemployed workers in Yugoslavia between the two world wars. The analysis investigates the legal, political, and institutional background to these hostels, and how they were conceived and financed. By looking at the development of a new public social policy from the perspective of the jobless, the article aims to examine the nature, goals, and especially the boundaries of a modern provision for Yugoslav workers, namely its strategies and practices of social inclusion and exclusion. The article reveals how a modern concept of unemployment gradually emerged. These hostels were not part of a traditional policy on poverty; they were the expression of a new and more modern form of social policy. The article further shows how new social differences and distances between "non-working" people were created, and what specific impact those differences and distances had on the functioning of these institutions.
\end{abstract}

\section{INTRODUCTION}

This article analyses the establishment of several hostels for unemployed workers in Yugoslavia between the two world wars. By examining the development of public social policy from the perspective of the jobless, it is possible to gain a good insight into the boundaries of modern provision for Yugoslav workers, namely its strategies and practices of social inclusion and exclusion. To explore the nature, goals, and limits of an emerging public engagement regarding the unemployed, one has to examine which social groups were targeted by this initiative, both theoretically and in practice. The aim of this approach is to investigate whether establishing hostels for

\footnotetext{
* I wish to thank Ulf Brunnbauer, Sabine Rutar, Laura Cerasi, Piero Brunello, and Eszter Varsa for their invaluable comments. Thanks are due, too, to three anonymous reviewers for suggestions that have considerably improved my argument.
} 
the unemployed in interwar Yugoslavia represented a traditional form of policy response to poverty, or whether - as I hope to demonstrate - it was the expression of a new and more modern form of social policy. ${ }^{\mathrm{I}}$ The analysis therefore investigates the legal, political, and institutional background to these hostels, and how they were conceived and financed. The article shows that new discourses on the unemployed developed slowly in Yugoslavia during these years, that a modern concept of "unemployment" gradually emerged, and that new hierarchies between "non-working” people were established. ${ }^{2}$

Regarding the workers' hostels, the article therefore investigates three main issues: the concrete local forms of enforcement of national legal measures; new forms of interaction between municipal and state authorities; and the actual practice of social policy in relation to the unemployed. The analysis of the specific regulations of the hostels and their application will show precisely how new social differences and distances were created, and what specific impact they had on the functioning of these institutions.

This implies taking a theoretical and methodological approach quite distinct from the main preoccupations of the historiography on interwar Yugoslavia of the past two decades. Most historical works focus on the "national question", on the political contest between centralists and anti-centralists, on the attempts to find compromises between the various national groups, as well as on the failure to find a solution to such questions - processes that radicalized the national rivalries and contributed to the end of the "first" Yugoslavia. ${ }^{3}$ Scholarly attention has also been

I. For the general development of social policies in Europe and the USA see, for instance, Peter Flora and Arnold J. Heidenheimer (eds), The Development of Welfare States in Europe and America (New Brunswick, NJ [etc.], I981); Jens Alber, Vom Armenhaus zum Woblfahrtsstaat. Analysen zur Entwicklung der Sozialversicherung in Westeuropa (Frankfurt am Main [etc.], 1982); Gerhard A. Ritter, Der Sozialstaat: Entstehung und Entwicklung im internationalen Vergleich, 3rd edn (Munich, 2010).

2. Christian Topalov, "The Invention of Unemployment: Language, Classification and Social Reform I880-1910”, in Bruno Palier (ed.), Comparing Social Welfare Systems in Europe (Paris, 1994), pp. 493-507; Bénédicte Zimmermann, Arbeitslosigkeit in Deutschland. Zur Entstehung einer sozialen Kategorie (Frankfurt am Main, 2006); Sigrid Wadauer, "Establishing Distinctions: Unemployment versus Vagrancy in Austria from the Late Nineteenth Century to 1938 ", International Review of Social History, 56 (20I I), pp. 3 I-70. See, more generally, Robert Castel, From Manual Workers to Wage Laborers: Transformation of the Social Question (New Brunswick, NJ, 2003).

3. For example Ivo Banac, The National Question in Yugoslavia: Origins, History, Politics (Ithaca, NY, 1984); John R. Lampe, Yugoslavia as History: Twice There Was a Country (Cambridge, 1996); Sabrina P. Ramet, The Three Yugoslavias: State-Building and Legitimation, I9I8-2005 (Washington DC, 2006); Holm Sundhaussen, Geschichte Jugoslawiens, 19I8-1980 (Stuttgart [etc.], I982); Jože Pirjevec, Il giorno di San Vito. Jugoslavia 1918-1922, storia di una tragedia (Turin, 1993); Dejan Djokić (ed.), Yugoslavism: Histories of a Failed Idea, 1918-1992 (London, 2003); idem, Elusive Compromise: A History of Interwar Yugoslavia (New York, 2007). 
devoted to the educational issues and cultural politics of this period, topics that again are often linked to "nation-building" issues. ${ }^{4}$

The present article, however, will focus on the fact that the political history of the country influenced the legislative process also in the social field. Furthermore, against the background of the existing major economic inequalities between the regions forming the newly established state, the crucial debate among Yugoslav politicians about state organization ("centralism vs federalism") was also linked to issues of redistribution and fiscal policy. Building on those dimensions, which have already been investigated, the following considerations on social and labour policies, with particular emphasis on the new facilities for the unemployed, aim to contribute towards a deeper understanding of the ongoing state-building process. The analysis of the public initiatives undertaken will allow us to reconstruct some aspects of the political culture of that time in relation to the poor and the unemployed, linking them with the development of new social policies, and the progressive affirmation of the ideology of state intervention in the economic and social field.

The studies undertaken on economic history, the history of the workers' movement, and welfare policies in interwar Yugoslavia will help me to frame the history I wish to narrate. ${ }^{5}$ To investigate the topic of this article, it is necessary to integrate and in some ways modify the approach used thus far in studies dealing with the history of work and social policy in the first Yugoslavia. To this end, I will concentrate on the local level, the micro-dimension, and its interaction with the state level. Furthermore, the focus will be on the new unemployment facilities, an under-researched topic. While the general framework of the development of social policies

4. Norbert Reiter and Holm Sundhaussen (eds), Allgemeinbildung als Modernisierungsfaktor. Zur Geschichte der Elementarbildung in Südosteuropa von der Aufklärung bis zum Zweiten Weltkrieg (Wiesbaden, I994); Martin Mayer, Elementarbildung in Jugoslawien (19I 8-194I). Ein Beitrag zur gesellschaftlichen Modernisierung? (Munich, 1995); Ljubodrag Dimić, Kulturna politika u Kraljevini Jugoslaviji 19I8-194I [Cultural Policy in the Kingdom of Yugoslavia 191 8-194I], 3 vols (Belgrade, 1996-1997); Andrew B. Wachtel, Making a Nation, Breaking a Nation: Literature and Cultural Politics in Yugoslavia (Stanford, CA, 1998); Ervin Dolenc, Med kulturno in politiko. Kulturnopolitična razhajanja v Sloveniji med svetovnima vojnama [Between Culture and Politics: The Cultural-Political Disagreements in Slovenia between the World Wars] (Ljubljana, 2010).

5. An excellent study of social history in the field is Marie-Janine Calic, Sozialgeschichte Serbiens 1815-194I: Der aufbaltsame Fortschritt während der Industrialisierung (Munich, 1994); see also idem, Geschichte Jugoslawiens im 20. Jabrhundert (Munich, 2010), pp. 97-109, I19-I22. On the general economic history of the period, see Sergije Dimitrijević, Privredni razvitak Jugoslavije od I9I8-I94I.g. [Economic Development of Yugoslavia 19I8-I94I] (Belgrade, I96I), and Gojko Polovina, Privredni sistem $i$ proizvodni odnosi u Jugoslaviji [Economic System and Production Relations in Yugoslavia] (Belgrade, 1958). Jozo Tomasevich, Peasants, Politics, and Economic Change in Yugoslavia (Stanford, CA, 1955) focuses on the economic development of the countryside. 
in Yugoslavia might already be well known, what was and was not done for those looking for a job still needs to be understood more precisely. The state level then has to be integrated with the municipal, the legislative dimension with the practice on the ground. Only by doing so will it be possible to interpret those developments and their relevance for an updated history of labour and of social policies in these regions.

Finally, considering the Yugoslav case will allow us to look at some common European developments from a "marginal" point of view, investigating a national case that has hitherto been completely neglected in the comparative historiography of European welfare policies. ${ }^{6}$ As evidenced by the last one and a half decades of research inspired by "global labour history", it might be very useful to look at the historical experience of semiperipheral countries. Deepening our knowledge of the Yugoslav case will contribute to a comparative history of labour and of European welfare policies, which would also include south-eastern Europe. ${ }^{7}$

\section{DEVELOPMENTS IN YUGOSLAV SOCIAL POLICY}

Those arriving in Belgrade by train in search of employment at the beginning of the I930s would have been greeted by large posters in the railway station advertising an intriguing initiative: hostels for jobless workers in the capital city. ${ }^{8}$ There had been two in the city since

6. The numerous studies of the history of European welfare policies during the twentieth century actually deal with western, southern, and northern Europe. On eastern Europe see Susan Zimmermann, "Wohlfahrtspolitik und die staatssozialistische Entwicklungsstrategie in der 'anderen' Hälfte Europas im 20. Jahrhundert”, in idem, Johannes Jäger, and Gerhard Melinz (eds), Sozialpolitik in der Peripherie. Entwicklungsmuster und Wandel in Lateinamerika, Afrika, Asien und Osteuropa (Frankfurt am Main [etc.], 200I), pp. 2 I I-237; Sabine Hering and Berteke Waaldijk, Guardians of the Poor-Custodians of the Public: Welfare History in Eastern Europe 1900-1960 (Opladen [etc.], 2006); Kurt Schilde and Dagmar Schulte (eds), Need and Care: Glimpses into the Beginnings of Eastern Europe's Professional Welfare (Opladen [etc.], 2005); Tomasz Inglot, Welfare States in East Central Europe: 1919-2004 (New York, 2008); Béla Tomka, Welfare in East and West: Hungarian Social Security in an International Comparison, I9I 8-I990 (Berlin, 2004). On the pre-I9I4 period see Susan Zimmermann, Divide, Provide, and Rule: An Integrative History of Poverty Policy, Social Policy, and Social Reform in Hungary under the Habsburg Monarchy (Budapest [etc.], 20I I).

7. Apart from deepening the knowledge of internal Yugoslav regional differences, a further development of this kind of investigation should actually relate the Yugoslav experiences more systematically with the international and transnational context to which they - like all developments in the field of social policy - belonged. See Christoph Conrad, "Wohlfahrtsstaaten im Vergleich: Historische und sozialwissenschaftliche Ansätze”, in Heinz-Gerhard Haupt and Jürgen Kocka (eds), Geschichte und Vergleich. Ansätze und Ergebnisse international vergleichender Geschichtsschreibung (Frankfurt am Main [etc.], 1996), pp. I55-180.

8. On the initial instructions for such posters see Istorijski arhiv grada Beograda [Historical Archives of Belgrade City; hereafter, IAB], 479 - Fond za stvaranje i održavanje radničkih ustanova u Beogradu [Fund for Establishing and Maintaining Workers' Institutions in Belgrade; 
February 1930, one for male and one for female workers, created to offer temporary relief for those who were not from Belgrade and who had arrived there attracted by the possibility of finding an occupation. ${ }^{9}$ After having been subjected to a short medical examination, the guests had to take a shower before they could enter the dormitory. The next morning they had to get up, wash, and dress in the dressing rooms before leaving the building. The hostels were one of a number of initiatives undertaken at that time throughout Europe for tackling vagrancy and, as in our particular case, for "supporting" public labour intermediation. ${ }^{10}$

Within a few years the institutions had clearly got a foothold and the hostels became very popular. One can deduce this not only from the statistics of the overnight stays in these institutions, but also from the activities of those malicious persons awaiting and approaching the newcomers at the railway station, leading them away under the pretence of guiding them to the hostels. It is not hard to imagine the outcome of such encounters, and the reports made to the police by those unfortunate enough to have been robbed speak for themselves. ${ }^{\text {II }}$ The posters were subsequently exhibited not only at railway stations but at all ports and arrival points in the city, including the river harbours of Belgrade and its suburbs Pančevo and Zemun, ${ }^{\mathrm{I}}$ on board the main watercraft that docked in those harbours, and at several other city institutions that unemployed workers had to approach. ${ }^{13}$

The hostels were an initiative of great importance for those travelling in search of a job and without the means to obtain private accommodation. There were many such travellers in those years, their number increasing

hereafter, FOND], box 58, folder 1929, 30 November 1929; subfolder 1929-1930. The "FOND" was a special institution in charge of managing support facilities for workers in Belgrade, the capital city of the Kingdom of Serbs, Croats, and Slovenes established in 1918. The FOND's management board comprised representatives of the Ministry of Social Policy and Public Health, the Municipality of Belgrade, and the Workers' Chamber.

9. IAB, FOND, box 58, "Poslovnik o upravljanju u radničkim skloništima" [Rules for the Management of Workers' Refuges; hereafter, "Rules"], 20 May 1929, art. I.

Io. Among the numerous and variegated institutions in this field, the most similar in comparison with the ones being examined here seem to be the "hostels" established in Austria in the interwar period, and derived from the previous Naturalverpflegsstationen of the late nineteenth century established in Habsburg Cisleithania, in some regions of the German Reich, in Switzerland, and the Netherlands; Wadauer, "Establishing Distinctions", pp. 32-33, 43-5 I. For analogous institutions in Habsburg Hungary, see Zimmermann, Divide, Provide, and Rule, pp. $6 \mathrm{I}-62$.

II. IAB, FOND, box 62, folder I933, the FOND to the Territorial Rail Direction, 30 September 1933 .

I 2. IAB, FOND, box 62, folder 1933, 31 October 1933; ibid., folder 1934, 2 January 1934, the FOND to the Direction of the River Traffic.

I3. IAB, FOND, box 62, folder 1933, the FOND to numerous organizations, 29 November I933. 
constantly throughout the I920s and especially the I930s, a time of great movements of people within the Yugoslav state due to the lack of work. Large numbers of jobless workers migrated from the countryside to the city, as well as from one Yugoslav region to another. Nevertheless, no overall evaluation of the phenomenon is possible on the basis of existing research. ${ }^{14}$

Until World War I, public unemployment assistance in the regions that later constituted the first Yugoslav state was, where it existed, essentially limited to the municipalities. ${ }^{\text {Is }}$ There are isolated cases of precedents of such hostels for the unemployed, such as the one in Zagreb, operative from 1907 to 1922, with twenty-five beds for men and thirty-five for women. The institution worked within the framework of a local employment bureau, it was financed by the municipality, and both employers and workers paid a fee for every intermediation. ${ }^{16}$

Such initiatives took place before a "modern" public social policy was shaped, which would conceive of the unemployed as a distinct group, would consider assistance to them (understood as distinguished from assistance to the poor), and would be not occasional but grounded on an officially acknowledged "right" of jobless people to be helped by the state. ${ }^{17}$ The intermediation between labour supply and demand, for instance, before World War I and also in the first postwar (i.e. Yugoslav) period was still primarily a municipal and later partly provincial duty. It lacked state legislation and coordination, and aid for the jobless still contained theoretical and practical features of the older local poor assistance. ${ }^{18}$

I4. Existing studies on internal Yugoslav labour mobility generally focus on the socialist and post-socialist periods. See, for instance, Biljana Sikimić, Petko Hristov, and Biljana Golubović (eds), Labour Migrations in the Balkans (Munich [etc.], 20I2). For an overview of the dramatic rise in unemployment in Yugoslavia during the period in question, and of increased interregional mobility, see Calic, Sozialgeschichte Serbiens, pp. 368-380, 390-393.

I 5 . This is valid for the former Habsburg regions, less so for the Kingdom of Serbia, and not at all for the Kingdom of Montenegro and the territories that, until the Balkan Wars, belonged to the Ottoman Empire, which itself had no form of public assistance specifically for the unemployed. In almost all the regions, however, for certain professional categories, above all miners and printers, there existed traditional forms of mutual aid in the event of unemployment. See Calic, Sozialgeschichte Serbiens, p. 230; Ilija P. Perić, Jugoslavensko socijalno zakonodavstvo. Priručnik za socijalnu službu [Yugoslav Social Legislation: Handbook for Social Services] (Belgrade, I93 I), pp. 230-23 I; Voijslav Petrović, Nezaposlenost $i$ staranje o nezaposlenima u Jugoslaviji do I94I godine [Unemployment and Assistance for the Unemployed in Yugoslavia until I94I] (Belgrade, I957), pp. 20-46.

i6. Zvonko Šešo, "Počeci djelovanja službe za zapošljavanje u Hrvatskoj" [The Beginnings of the Employment Service in Croatia], Revija za socijalnu politiku, 7 (2000), pp. 175-I 82.

17. For a comparative view see Alber, Vom Armenhaus zum Woblfahrtsstaat, pp. I66-i 94; Hans-Jürgen Bieling and Frank Deppe (eds), Arbeitslosigkeit und Woblfahrtsstaat in Westeuropa. Neun Länder im Vergleich (Opladen, 1997); Zimmermann, Divide, Provide, and Rule, pp. $64-68$.

I 8. For a particularly harsh, but not unfounded, judgement on these continuities, see Dušan Lakićević, Misao i praksa socijalne politike Jugoslavije između dva svetska rata [Theory and 
Between I92I and I922 the first new Yugoslav labour legislation was enacted. After the constitution of I92 I had established a legal framework - for the first time in these regions - for some "social rights", being regarded therefore as marking the birth of the idea of a modern welfare state for this country, ${ }^{19}$ a "Law on compulsory workers' insurance" was proclaimed in May 1922, ${ }^{\circ}$ followed by a "Law on workers' protection" in June of the same year. Both laws were strongly influenced by the Treaty of Versailles, which required the countries involved to implement some socio-political principles, including the introduction of an eight-hour day, union freedom, and the prohibition of child labour. The subscribers were also obliged to become members of the International Labour Organization (ILO), founded in I919 as an institution of the League of Nations. There is a broad consensus among scholars that social insurance and labour legislation in Yugoslavia were not the result of industrialization, nor of parliamentary action by bourgeois parties, nor of extra-parliamentary pressure on the part of the workers' movement, but above all the result of international agreements. $^{21}$

Furthermore, the reasons for the relatively late and limited development of a welfare state in the first Yugoslavia are generally attributed to two main factors: the economic structure of industry, dominated by small and medium-size enterprises and so without large concentrations of workers comparable with those in western European industrial cities; and the peculiarities of the Yugoslav working classes, not only small from a quantitative point of view, but also extremely heterogeneous and still firmly linked to farming activities. ${ }^{22}$ Workers' movements were thus, especially in the 1920 , very fragmented, quite limited in quantitative terms, and not very effective in their organizational capacity. This situation changed somewhat in the mid-I930s when a large wave of strikes, raising mainly wage-related issues, took place in many Yugoslav cities. ${ }^{23}$

Practice of Social Policy in Yugoslavia Between the Two World Wars] (Belgrade, 1976), p. 98. For a good overview of assistance to the unemployed until 1918, see Petrović, Nezaposlenost, pp. 20-46. 19. Perić, Jugoslavensko socijalno zakonodavstvo, p. 96; Jovica Luković, "Der ferne Staat. Transfer als Institutionalisierungsvehikel der Sozialversicherung in Jugoslawien (I9I9-I94I)", in Wim van Meurs and Dietmar Müller (eds), Institutionen und Kultur in Südosteuropa (Munich [etc.], 20I4), pp. 2 I I-240, 217-2 I 8.

20. Several professional groups (ploughmen, artisans, servants) and the jobless were excluded from these forms of insurance; Perić, Jugoslavensko socijalno zakonodavstvo, pp. I57-160.

21. Calic, Sozialgeschichte Serbiens, p. 229; Luković, "Der ferne Staat”, pp. 222-223; Milica Milenković, "Radničko zakonodavstvo i radničke socijalne institucije u Jugoslaviji I9I8-194I" [Labour Laws and Worker Social Institutions in Yugoslavia, I9I8-194I], Tokovi istorije, I-4 (1999), pp. I06-i 17. Cf. Perić, Jugoslavensko socijalno zakonodavstvo, pp. 78-94.

22. Calic, Sozialgeschichte Serbiens, pp. 234-235.

23. Kosta Nikolić, "Radnici u građandskom društvu Kraljevine SHS/Jugoslavije" [Workers in the Civil Society of the Kingdom of the Serbs, Croats, and Slovenes/Yugoslavia], Godišnjak za 
Nevertheless, and despite the vast, detailed but sometimes "ideologized" literature of the socialist era concerning trade-union movements and workers' strikes, the question of the making of the working classes, and especially the history of social conflict in this period still await adequate treatment. ${ }^{24}$ The degree of contention around these new laws is thus not easy to gauge. Although we quickly learn that the relevant laws, such as the ones mentioned above, were approved almost without any parliamentary debate, ${ }^{25}$ and that also academic discussion in relation to them was absent, ${ }^{26}$ the new socio-political measures encountered, at the same time, resistance from many sides. ${ }^{27}$ This article will shed further light on some of the political contestations related to the initiatives for the jobless, but the main issue underlying political and social conflict in relation to social policy in these years certainly deserves to be investigated further.

Apart from the international context in general and the ILO in particular, there were two other main factors that influenced the formation of a new Yugoslav social policy. On the one hand, the country was in economic difficulties and unemployment rose dramatically. The major cities had already been invaded in the late I 920 s by men and women in search of jobs; those unable to find jobs crowded the streets, making the question of mass unemployment extremely "visible" and an issue of public concern. ${ }^{28}$ On the other hand, the authoritarian-style and centralistic reforms carried out at national level during the I930s that were characterized by stronger state intervention in the economic and social fields, also had an impact on the new social policies.

The country, a parliamentary monarchy, was actually a fragile construction, and ethno-political tensions merged with social and economic cleavages, undermining the state's stability. In an effort to hold Yugoslavia together, on 6 January I929 King Aleksandar abolished the I92I constitution, dismissed the elected parliament, and banned all ethnically based political parties, establishing a "royal dictatorship" and promoting

drustvenu istoriju, I (1994), pp. 67-76; Mira Kolar-Dimitrijević, "Socijalno-ekonomska politika gradske općine Zagreba s obzirom na položaj radničkog stanovništva od velike svjetske krize do početka drugoga svjetskog rata (193 I-39)" [Socio-economic Policy of the Municipality of Zagreb with Regard to the Condition of the Working Population from the Great World Crisis to the Beginning of the Second World War (193 I-39)], Povjesni prilozi, I (1983), pp. I7I-244, 216-222.

24. Calic, Sozialgeschichte Serbiens, pp. 254-257.

25. Perić, Nezaposlenost, p. 72.

26. Luković, "Der ferne Staat", p. 222.

27. See some of the references in Calic, Sozialgeschichte Serbiens, pp. 4I 3-4I4, 430-43 I; KolarDimitrijević, "Socijalno-ekonomska politika"; Nikolić, "Radnici u građandskom društvu Kraljevine”.

28. Calic, Sozialgeschichte Serbiens, p. 380. 
several centralizing reforms. The Octroyed Constitution of I93 I did not mean a return to an independent parliament, although press censorship and other political restrictions were relaxed. With the assassination of King Aleksandar during a visit to Marseilles on 9 October I934, the ascent began of the distinguished economist and former finance minister Milan Stojadinović, who was nominated prime minister in June 1935. He remained in office without interruption until February I939, longer than any other interwar prime minister. He also greatly influenced interwar Yugoslav economic policy.

By the mid-I930s there was a slow economic upturn in the country, linked to Stojadinovićs new economic and social policy. Following developments taking place in the United States and in several other European states, ${ }^{29}$ the prime minister was resolute in insisting that the national economy be oriented, sustained, and defined by the state. As a result, tax concessions were introduced for industrial enterprises, a number of peasant debts were cancelled, the state invested in industry and military production, state companies and monopolies were established, and a long series of "public works" were promoted. The latter, financed through domestic and foreign loans, was one of the initiatives undertaken by the state in order to keep unemployment down. In addition, a new law promulgated in 1938 increased from six to twenty-six weeks a year the length of time during which one could receive welfare. ${ }^{30}$

These were weak and inadequate measures for coping with the unemployment spreading across the country. Nevertheless, they were the expression of a change that was occurring in Yugoslav political culture and social policy, a change that had begun in the late i92os. Apart from the early steps taken to enforce a new labour legislation, leading politicians became progressively aware of the importance of developing and implementing a modern social policy. It was summarized by Drago Marušić, minister for social policy and public health, in his introduction to the first issue of the monthly periodical Socijalni arbiv, where he declared that "building a social policy" ought to be one of the first tasks of a modern state. ${ }^{3 \mathrm{I}}$ The shift from past practices was explained clearly by Slobodan Vidaković, an influential sociologist and social reformer, who stressed the urgency of adopting strong state interventionism in the social field and argued that "social politics is not a philanthropic activity of some

29. See notes I and 6, and Andrea Rapini, "I 'cinque giganti' e la genesi del Welfare State in Europa tra le due guerre", Storicamente, 8 (20I2), art. 8, DOI I0.1473/stor4Io, http:// www.storicamente.org/os_studi_ricerche/rapini_stato_sociale.htm.

30. Calic, Sozialgeschichte Serbiens, pp. 404-416, 427-432; Lampe, Yugoslavia as History, pp. I77-1 81; Sundhaussen, Geschichte Jugoslawiens, pp. 84-98.

31. Drago Marušić, "Glavne smernice naše socijalne politike" [Guidelines of Our Social Policy], Socijalni arhiv [hereafter, SA], I935, I, pp. I-3. 
generous men or municipalities", it must be a duty of public (state, regional, and municipal) authorities. ${ }^{32}$ One could also read that "Social policy cannot remain a concern of humanitarian work and of individual generosity [...]. The state is faced with a series of problems which it has to solve with planned efforts and great impetus, because only such systematic and large-scale action can guarantee technical and financial success." 33

Between 1922 and 1927, before the world economic crisis, Yugoslav governments did not devote much attention to the issue that most concerns this article, namely unemployment and facilities for the unemployed, focusing rather, as we have seen, on the first state-aid measures for "workers"; but later, new approaches to the question slowly took shape. From a legislative point of view the turning point is 1935, when the legal grounds for unemployment insurance were created. But, even earlier, important measures had been taken to support jobless people. The most important was the institutionalization (I92I-I922) of the "state" labour offices, which had replaced the municipal, provincial, and private structures of the past. At the same time, a "central agency for the labour offices" (Central Agency) was established in Belgrade to coordinate the activities of the local labour offices. A tax for the latter was introduced in I922 as a specific fund for the unemployed. The service was financed almost entirely by employers and insured workers. ${ }^{34}$

The system as a whole did not begin to operate properly until the end of the I920s, but the tax had been collected from the beginning of the decade. By 1928 , then, approximately 5 million dinars had been paid into the fund. ${ }^{35}$ In 1928 the Central Agency obtained a high degree of autonomy, allowing it to manage the funds with greater efficacy. They were designated first and foremost for the municipalities in the form of zero- or very low-interest loans, and with the explicit aim of providing the necessary structures for labour intermediation and for what was to

32. Slobodan J. Vidaković, Naš socijalni problemi [Our Social Issues] (Belgrade, 1932), p. 25. All quotes from Serbian and Croatian have been translated by the author.

33. The Editorial Board, "Naše građevine" [Our Buildings], SA, I935, 3-4, pp. 4I-48, 43.

34. Perić, Jugoslavensko socijalno zakonodavstvo, pp. 363-368. A collection of legislative measures specifically relating to the unemployed can be found in idem, Zakonodavstvo o zbrinjavanju nezaposlenih $u$ Jugoslaviji [Legislation on Assistance for the Unemployed in Yugoslavia] (Belgrade, 1939).

35. Idem, "Rezultati Javne službe posredovanja" [Results of the Public Service for Job Intermediation], $S A$, 1935, 3-4, pp. 49-59, 50. The exchange rate for the dinar during the interwar period fluctuated between US\$r.70 (I925) and US\$2.3I (1938) (quotations on the New York Stock Exchange); Ingvar Svennilson, Growth and Stagnation in the European Economy (Geneva, 1954), p. 2, quoted in Goran Nikolić, Kurs dinara $i$ devizna politika Kraljevine Jugoslavije 19I8-I94I [Exchange Rate of the Dinar and the Foreign Currency Policy of the Kingdom of Yugoslavia] (Belgrade, 2003), p. 47. 
become, from the mid-I930s onwards, the main focus of the Central Agency and its institutions: unemployment benefit. Furthermore, several forms of financial aid were envisaged (mostly, but not exclusively, for the unemployed), as well as a system of benefits to meet the costs of train and ferry tickets, ${ }^{36}$ programmes of "public works", and "social housing", which envisaged the construction of several types of residential buildings for workers. ${ }^{37}$ This shows that the hostels that this article deals with were part of a broader set of social policies that were evolving, including labour protection, social security, and - as we will see - policies of poverty relief. Within the framework of this public intervention, specific laws were gradually designed for the unemployed, and enforced through concrete initiatives.

These measures represent a transition from the idea of occasional assistance to the poor towards structural assistance to the "modern" unemployed, i.e. those who were increasingly considered victims of the modern economic and industrial system. A change in the public perception of unemployment had been occurring since the turn of the twentieth century, both in Europe as a whole and, later, in Yugoslavia: the notion of unemployment as a "structural" result of the modern industrial economy was progressively added to the existing concept of the non-worker as a result of personal and temperamental reasons (above all "laziness"). ${ }^{8}$

Common opinion was sometimes hostile to jobless people: "You often hear it said that, if they had the wish to work, they would have found a job." ${ }^{39}$ But a new understanding of the condition of people without an occupation was emerging, and unemployment began to be defined as "of a social, not a personal nature" ${ }^{4^{\circ}}$ In 1930 a report by the Fund for Establishing and Maintaining Workers' Institutions in Belgrade claimed that "actual unemployment is not seasonal unemployment, which is short-term and does not afflict all kinds of work, but is a consequence of the world economic crisis and therefore it lasts longer and afflicts all kinds of work" ${ }^{4}$

Throughout the various texts related to this topic, we frequently find references to "no-fault" unemployed persons, those who continued to be

36. Perić, Jugoslavensko socijalno zakonodavstvo, pp. 309-337.

37. Ibid., pp. 355-363; Petrović, Nezaposlenost, pp. I09-I 26.

38. Topalov, "The Invention of Unemployment"; Wadauer, "Establishing Distinctions"; Zimmermann, Arbeitslosigkeit, pp. 27-68; Manfredi Alberti, La "scoperta" dei disoccupati. Alle origini dell'indagine statistica sulla disoccupazione nell'Italia liberale (I893-19I5) (Florence, 2013), pp. $65-83$.

39. Svetozar Ritig, Member of the City Council of Zagreb, quoted from the minutes of the City Council meeting of 23 June 1932, in Kolar-Dimitrijević, "Socijalno-ekonomska politika", p. 188 .

40. Vidaković, Naši socijalni problemi, p. I7.

4I. IAB, FOND, box 62, Cetvrti godišnji izvestaj [Fourth Annual Report] (Belgrade, 1933) [hereafter, IAB, Fourth Annual Report I933], p. 19. 
without a job because of the system and as a consequence of the economic crisis. A good illustration of this is the analysis provided in the "Handbook for Social Services" published in I93 I by the Central Agency for Job Intermediation. It aimed to explain the new "Yugoslav social legislation": "under the concept of 'unemployment' we understand those circumstances of non-work into which the worker has consciously fallen because of justifiable reasons or against his will [...]. Therefore we are not interested in that kind of unemployment which was born voluntarily out of unjustifiable reasons." ${ }^{2}$ Even clearer was the distinction regarding the causes of unemployment, which were divided into two subgroups: (I) "subjective" ones, if the worker is unable to work, or if he "does not want to work because of laziness"; and (2) "objective" reasons, when the worker cannot find a job because there is no job on offer. After sketching the general history of unemployment, the report reaches a limpid conclusion: "Therefore, and with regard to its long-lasting character, unemployment has today become a phenomenon which imposes itself with an uncontrolled force on the entire world as a serious socio-political problem, and on whose solution social structures of the future will depend." 43

The shift in the perception of this social phenomenon is well represented by the changed approach of Stjepan Srkulj. When he began his second mandate (1928-1932) as mayor of Zagreb, he was still a representative of the "old school", convinced that the unemployed do not like to work, treating unemployment as a poverty-related issue, and maintaining that social care for jobless people should not come under municipal jurisdiction. In the course of the following years, however, he changed his views: "The city municipality $[\ldots]$ neither can nor should simply pass over this relevant question of mitigating social misery." He began to support welfare institutions, especially those for the unemployed. ${ }^{44}$

Srkulj's opinion was not an isolated one. Similarly, his successor, Ivo Krbek, defined unemployment as "one of the greatest social adversities of the present" ${ }^{45}$ implying, by extension, that it was not an individual issue. It is therefore not by chance that in 1923 the municipality of Zagreb had

42. Perić, Jugoslavensko socijalno zakonodavstvo, pp. 194-199, 195. On the long tradition of such distinctions, see Bronisław Geremek, Truands et misérables dans L'Europe moderne, 1350-I600 (Paris, 1980); Stuart J. Woolf, The Poor in Western Europe in the Eighteenth and Nineteenth Centuries (London, 1986). On the continuities in general and comparative terms, see, for instance, Andreas Gestrich and Lutz Raphael (eds), Inklusion/Exklusion. Studien zur Fremdheit und Armut von der Antike bis zur Gegenwart (Frankfurt am Main [etc.], 2004); Andreas Gestrich, Steven King, and Lutz Raphael (eds), Being Poor in Modern Europe: Historical Perspectives $1800-1940$ (Berlin [etc.], 2006).

43. Perić, Jugoslavensko socijalno zakonodavstvo, p. I97.

44. Quoted in Kolar-Dimitrijević, "Socijalno-ekonomska politika", pp. I8 I-I 82.

45. Quoted in ibid., p. 196. 
rejected the first proposal to open a workers' hostel, when unemployed assistance was still equated with poor relief and delegated to private humanitarian associations. ${ }^{46}$ In the first half of the 1930 , the political orientation of the municipality changed, and the decision to construct with public money - several buildings for the unemployed, including a workers' hostel, was approved.

Such developments were not univocal, linear, and uncontested: Krbek's successor, Rudolf Erber, who served as Zagreb's mayor between I934 and 1936, was an outspoken opponent of these social initiatives. During his mandate he gave shape to a marked "antisocial and antiworker policy", preferring to promote repressive measures rather than social aid, and merging unemployment provision with poor relief. ${ }^{47}$ Therefore, one must not take it for granted that the municipalities would promptly accept government financial aid and the responsibility for building workers' facilities, and developments similar to the ones in Zagreb can also be found elsewhere, in Belgrade for example: "The social consciousness of our municipalities was at that time less than today, and we owe it only to the vice-president of Belgrade's municipality of that time, the meritorious social reformer Dr Kosta Jovanovic, that the municipality decided to accept this gift, which it had refused some years before." ${ }^{8} 8$

Despite criticism and resistance, the progressive emergence of a peculiar social profile of the "unemployed" can be observed, and the establishment of aid facilities specific to the unemployed made them distinct from classical forms of poverty relief measures. The latter were traditionally managed by private associations, in collaboration - especially beginning from the I930s - with the municipalities, and articulated through several initiatives and institutions. The aid was rarely monetary, and instead took the form of gifts of food, particularly during the winter, as well as clothes and wood. Furthermore, a major role was played by soup kitchens. ${ }^{49}$

46. Šešo, "Počeci djelovanja", p. I78.

47. Kolar-Dimitrijević, "Socijalno-ekonomska politika", p. 2 I 5.

48. Editorial Board, "Naše građevine”, p. 43.

49. See for example [Anon.], "Delatnost 'Pučke kuhinje' u Vinkovcima” [The Activities of the Soup Kitchen in Vinkovci], [Anon.], "Rad 'Gradske kuhinje' i javni radovi u Subotici” [The Work of the Municipal Kitchen and Public Works in Subotica], [Anon.], "Zimska pomoć siromašnom i nezaposlenom građanstvu grada Bitolja" [Winter Aid for the Poor and Unemployed Population of the City of Bitola], $S A$, 1936, I-3, pp. 47-48; Mira Kolar-Dimitrijević, Prvo zagrebacko dobrotvorno drustvo Drustvo čovječnosti, I846-1946. [The First Humanitarian Society in Zagreb "Društvo čovječnosti" I 846-1946] (Zagreb, 1998). For some regional overviews see Darja Zaviršek and Vesna Leskošek, The History of Social Work in Slovenia, and Sandra Prlenda et al., History of Social Work in Croatia, 1900-1960, final reports of the international research project "History of Social Work in Eastern Europe 1900-1960", at http:// www.sweep.uni-siegen.de. 
Specific semi-public and private institutions were appointed to manage this kind of activity. ${ }^{50}$

Facilities for the unemployed, and especially the workers' hostels, have to be clearly distinguished from all these services:

First of all, workers need to know that the Male Workers' Hostel is not a refuge for poor people. It is not a product of charity. The unemployed worker doesn't come there for begging. There is nothing to be ashamed of when he crosses its doorstep. He must go in with his head up. ${ }^{\text {SI }}$

The dignity of workers is linked to the non-humanitarian character of the institution:

[...] because the Workers' Hostel is a social institution, built with public money. The aim is not to hold poor people in their poverty, but to help the unemployed worker to find a job. [...]. By building the Workers' Hostel the state (because in fact the state erected it, although it is called "municipal”) didn't take on the role of the rich man who deals with charitable works in order to please God. ${ }^{52}$

Hostels for the unemployed were something new, ${ }^{53}$ and their function therefore required explanation. Occasionally, the press published strong criticisms, accusing the Central Agency of squandering public money by erecting buildings, instead of helping needy people. However, the Central Agency's response was that, as much as refuges, sanatoria, and hospitals are of crucial importance to tuberculosis patients, the same applies to the hostels and other facilities for the unemployed. ${ }^{54}$ In general, the Central Agency considered the aid provided by the hostels a "real blessing" for workers, in spite of the inevitable practical compromises. ${ }^{55}$ Indeed, most

50. In the larger cities, for example Zagreb and Belgrade, there were some specific "associations" under the auspices of the social departments of the municipalities (so-called "Societies for Helping the Poor and Fighting Beggary”). See Slobodan Ž. Vidaković (ed.), Zdravlje i socijalna pomoć u Beogradu za 1935 i I936 godinu [Health and Social Care in Belgrade in 1935 and 1936] (Belgrade, 1937), pp. 376-381; Državni Arhiv Zagreb [State Archives of Zagreb; hereafter, DAZ], SO, box 5, "Izvještaj Društva za pomaganje sirotinje i suzbijanje prosjačenja u Zagrebu" [Report of the Society for Helping the Poor and Fighting Beggary in Zagreb]; Dimitrije J. Stojanović, "Rad Društva za zaštitu sirotinje i suzbijanje prosjačenja u Beogradu" [The Activities of the Society for Protecting the Poor and Fighting Beggary in Belgrade], Beogradske opstinske novine, I 2 (1933), pp. 723-730.

51. "Radničko sklonište od juče prima nezaposlene" [Since Yesterday the Workers' Hostel Accepts the Unemployed], Politika, I November 1929. Unless noted otherwise, none of the press articles cited identify the author.

52. Ibid.

53. From the point of view of the social history of architecture. See Zlata Vuksanović-Macura, Zivot na ivici. Stanovanje sirotinje u Beogradu 1919-194I [Living at the Fringe: Housing Conditions of the Poor in Belgrade, I9I9-I94I] (Belgrade, 20I 2), p. Io9.

54. [Anon.], "Svečano otvorenje doma Javne berze rada u Splitu" [Solemn Inauguration of the Building for the Public Labour Office in Split], $S A$, I935, 5-6, p. 86.

55. Editorial Board, "Naše građevine", p. 44. 
of the press had first vigorously promoted the establishment of the hostels examined here, ${ }^{56}$ and then, notwithstanding criticism regarding some minor aspects, celebrated their opening. ${ }^{57}$

Such institutions were also a representation of society and its relation to "work", of normative social models, and of deviations from those models. "Nature", a colonel in the gendarmerie writing in a police journal wrote, "drives the man to work" $5^{8}$ Not working would therefore be "unnatural" and dangerous for mental health, "as demonstrated by the psychiatrists". One needs "to distinguish carefully between those unemployed persons who remained unemployed because it was impossible to find a job, and the professional unemployed".59

Begging and vagrancy were crimes punished by detention and forced labour, ${ }^{60}$ although, in practice, beggars were often banned from the city or, if they were foreigners, from the state, especially in cases of recidivism. ${ }^{6 r}$ If beggars and vagrants were simply to be repressed or removed, it was possible to help at least some of the unemployed by reintegrating them into the labour market and thereby into "natural", "normal" society. If the unemployed were also homeless, however, they occupied a much more disadvantaged place in that social order. The police may well have been sent, as can be read in the press of that time, to arrest those who were sleeping in the town parks, but "it is not opportune", commented a journalist, "to devolve upon the police the task of solving the social question of unemployment" ${ }^{62}$

56. In the case of Zagreb, for instance, which was "late" in comparison with the other main Yugoslav cities: "Prenoćište za siromašne radnike" [Hostel for Poor Workers], Jutarnji list, I9 November I93 I; "Što je s radničkim konačištem i radničkom kuhinjom?” [What's Going on with the Workers' Refuge and the Workers' Kitchen?], Novosti, is June 1932; “O nevoljama neuposlenih radnika" [About the Troubles of Unemployed Workers], ibid; "Otvaranje radničkog prenoćišta” [Opening of the Workers' Hostel], Večer, 2 I February 1933.

57. "Krevet za četiri dinara. Prenoćište kraj novog sajmišta otvoreno ali slabo posjećeno" [A Bed for Four Dinars. The Hostel Beside the New Fair Opened but Poorly Used], Jutarnji list, I9 April 1933; "I4.554 radnika” [14,554 Workers], Novosti, 9 May I934.

58. D. Stefanović, "Nezaposlenost kao socijalno-ekonomski uzrok kriminaliteta” [Unemployment as Socio-economic Reason for Criminality], Policija, 1932, 5-6, pp. 236-242; 1932, 7-8, pp. 355-365, 357 .

59. Ibid., pp. $362-363$.

60. See the "Law for the State Protection" (6 January 1929), art. 6, Službene novine, i I January 1929, or the Criminal Code of the Kingdom of Yugoslavia (27 January 1929), §1 58, Službene novine, 27 January 1929. Regarding the wide and varied social sphere of "vagrancy", see, in relation to the Austrian case and with useful theoretical considerations, Wadauer, "Establishing Distinctions", pp. 31-70. See, in general, A.L. Beier and Paul Ocobock (eds), Cast Out: Vagrancy and Homelessness in Global and Historical Perspective (Athens, OH, 2008); Beate Althammer (ed.), Bettler in der europäischen Stadt der Moderne: Zwischen Barmberzigkeit, Repression und Sozialreform (Berlin [etc.], 2007).

6r. See the huge number of similar cases published in Policijski glasnik, the official police bulletin.

62. "Što je s radničkim konačištem i radničkom kuhinjom?". 
The workers' hostels examined in this article are an expression of this shift in political culture in interwar Yugoslavia.

The concern of public authorities with the issue of "hygiene" also played an important role in prompting and shaping these state and municipal interventions. Concerning the mass of workers who came from all over Yugoslavia, one could read that since "they [were] not well-fed, tired, and consumed by their lives, having spent their existence in really difficult economic and hygienic conditions", they were "very often carriers of dangerous and serious epidemic diseases". ${ }^{63}$ It was explained that "the very important preventive function regarding the social hygiene" performed by these hostels "can never be stressed enough". Otherwise, "these miserable jobless workers would very often carry and sow numerous infectious diseases among the population of Belgrade" ${ }^{64}$ As a consequence, these institutions represented "the altar of the workers' health". ${ }^{65}$

Finally, it was also a symbolic issue, a matter of "pride" for the municipality and the town community, since social institutions began to represent "the pride of a community and an expression of its cultural level". ${ }^{66}$ In the case of Belgrade, we are dealing with a city that was also the capital of a state and had the "honour" to represent the entire country. In the mid-r930s there was a great preoccupation with the "enormous masses [which] moved from the hinterland to Belgrade and always have a fully unsafe existence", so that "Belgrade, once the city with the strongest economic business, is acquiring the aspect of a city of social misery". ${ }^{67}$ The wish, therefore, was for Belgrade's relief facilities to become, through such initiatives, "the most attractive place in the list of Yugoslav institutions of this kind". ${ }^{68}$ By doing so,

[...] the municipality of Belgrade will raise the flag of social policy above all others in the country and in the Balkans, just as Prague had recently raised it above all of Central Europe. Belgrade must do it. This corresponds both to its historical development, and to the spirit of its citizens. ${ }^{69}$

63. Vidaković, Zdravlje i socijalna pomoć, pp. 371-372.

64. Ibid.

65. IAB, FOND, box 58, "Govor G. Luke Pavićevića”, s.d. (this document is the typescript of the inaugural address held by the secretary of the FOND at the ceremony for the opening of facilities in Belgrade on 9 February 1930). See also Željko Dugac, "Like Yeast in Fermentation': Public Health in Interwar Yugoslavia”, in Christian Promitzer et al. (eds), Health, Hygiene and Eugenics in Southeastern Europe to 1945 (Budapest, 201 I), pp. 193-232.

66. "Što je s radničkim konačištem i radničkom kuhinjom?".

67. Vidaković, Zdravlje i socijalna pomoć, p. 274.

68. Ibid., p. 374.

69. Ibid., p. 278. Note the allusion to Prague, which illustrates the importance of interregional points of reference. 
Belgrade and Yugoslavia were projected as the "lighthouse" of the Balkans, and this extended even to the social field. The building of hostels for unemployed workers acquired more overtly political values here, because "they will perform a humanitarian and social, as well as economic and national task. Because to preserve the health of the young labour force [...] means to preserve a reserve labour force for the needs of our economy". 70 "Health", "labour", "economy", and "nation": every initiative in this field "is really a patriotic and state-building one" ${ }^{7 \mathrm{I}}$

\section{BUILDING THE HOSTELS}

Some pre-existing buildings were restructured, but more often new buildings were erected to house the labour offices, (male and female) workers' hostels, soup kitchens, and public baths. The precise dynamics of funding differed from case to case, but in general the municipalities, aside from making the sites available for free and investing amounts derived from their own budgets, often received loans from the Central Agency, obtaining additional subventions from the local workers' chambers $^{72}$ and the local labour offices.

When, on I9 May 1935, Pero Blašković, a member of the presidency of the Central Agency, addressed those attending the inauguration of the new public labour office in Split, which included a workers' hostel, he said: "You don't owe gratitude to anybody, because it rose from the sweat and corns of workers, and from the devotion of employers." ${ }^{3}$ The money was, in fact, collected in the province of Split and, after having been held in Belgrade by the Central Agency for several years, finally returned to fund the building of Split's labour office and the new workers' hostel.

Similarly, for the women workers' hostel in Ljubljana (opened on 30 August 1937) an interest-free loan (I,700,000 dinars) was made by the local labour office. ${ }^{74}$ In Novi Sad a loan was granted by the Central Agency. ${ }^{75}$

70. IAB, FOND, box 58, "Govor G. Luke Pavićevića”, italics mine.

7I. Editorial Board, "Naše građevine", p. 42. Social policy conceived as a matter of national prestige and as a tool for state-building was a characteristic trait of eastern European interwar governments; Zimmermann, "Wohlfahrtspolitik", pp. 2 I 2-2 I 4; Inglot, Welfare States, pp. $54-59$.

72. The Workers' Chambers (Radničke komore) were public institutions (i.e. they were not trade-union organizations) that represented workers' interests; they received public funding and were linked to the Ministry of Social Policy; see Milenković, "Radničko zakonodavstvo", pp. IO8-I IO.

73. [Anon.], "Svečano otvorenje".

74. [Anon.], "Otvaranje prenočišta za radnice u Ljubljani” [Opening of Women Workers' Hostel in Ljubljana], SA, I937, 9-10, p. 285 .

75. Arhiv Jugoslavije [Archives of Yugoslavia; hereafter, AJ], Središnja uprava za posredovanje rada [Central Agency for Job Intermediation], box I, subfolder 3, final approval by the Minister, 30 May 1932. 
In 1929 a considerable loan ( 10 million dinars) funded by the local labour offices was extended to the municipality of Belgrade, which had been charged with constructing several buildings and institutions in the capital to assist jobless workers, breast-feeding working mothers, and the children of the unemployed. ${ }^{76}$ The municipality of Zagreb, in 1932, did not take out loans, but received subventions, and not directly from the Central Agency but from local institutions linked to it and to the Ministry of Social Policy and Public Health, such as the local workers' chamber ${ }^{77}$ and the labour office. $^{78}$

By 1935 the Central Agency had already distributed around 23 million dinars through loans for the construction of "workers' buildings" (labour offices, hostels, soup kitchens, and public baths) throughout the country.79 To this economic support we should add the occasional subventions by various agencies: the Central Agency itself, the king, the Ministry of Social Policy and Public Health, the provinces, workers' chambers, and the municipalities themselves. ${ }^{80}$ This means that, even in times of profound economic crisis, the municipalities and many other public institutions directed a share of their budgets to these structures and their maintenance. ${ }^{8 \mathrm{I}}$

It is important therefore to recognize a synergy between "central" and "local" authorities, between the state and the municipalities, with funds coming primarily from workers' and employers' contributions, and marginally from other forms of public - state and municipal - taxation. The creation of jobless workers' hostels and other facilities was due therefore not to an exclusively municipal dynamic or, for that matter, to

76. For more context on the Belgrade case, see Vidaković, Zdravlje i socijalna pomoć, pp. 370-374. Regarding the loan, it was considered "actually a present"; Editorial Board, "Naše građevine", p. 43 .

77. DAZ, I0-8, Gradsko poglavarstvo Zagreb, Socijalni odsjek I9I9-I937 [City Municipality of Zagreb, Social Department; hereafter, SO], box 2, Workers' Chamber to the Municipality, 6 October 1932.

78. DAZ, SO, box 2, Central Agency to the Labour Office in Zagreb, 27 July 1932. The municipality also contributed to the building costs. This is later confirmed in DAZ, SO, box 2, "Izvještaj o radu i poslovanju u Gradskom radničkom prenoćištu u Zagrebu u budžetskoj godini 1936-1937" [Report on the Activities and the Management of the City Workers' Hostel in Zagreb for the Budget Year 1936-1937; hereafter, DAZ, "Final Report 1937"].

79. Perić, "Rezultati Javne službe posredovanja”, p. 52. For the detailed lists see AJ, Središnja uprava za posredovanje rada, box I, subfolder 3 .

80. Detailed examples of all these subventions can be found in IAB, FOND, subfolders 1935 , 1938, 1939.

8I. In 1938 in Belgrade 13 million dinars were collected and used for this purpose; IAB, FOND, box 59, Deveti godišni izvestaj Fonda za stvaranje $i$ održavanje radničkih ustanova $u$ Beogradu o radu u 1937/38 budžetskoj godini [Ninth Annual Report of the Fund for Establishing and Maintaining Workers' Institutions in Belgrade on Activities During the Budget Year 1937-1938] (Belgrade, 1938) [hereafter, IAB, Ninth Annual Report 1938], p. 3. 


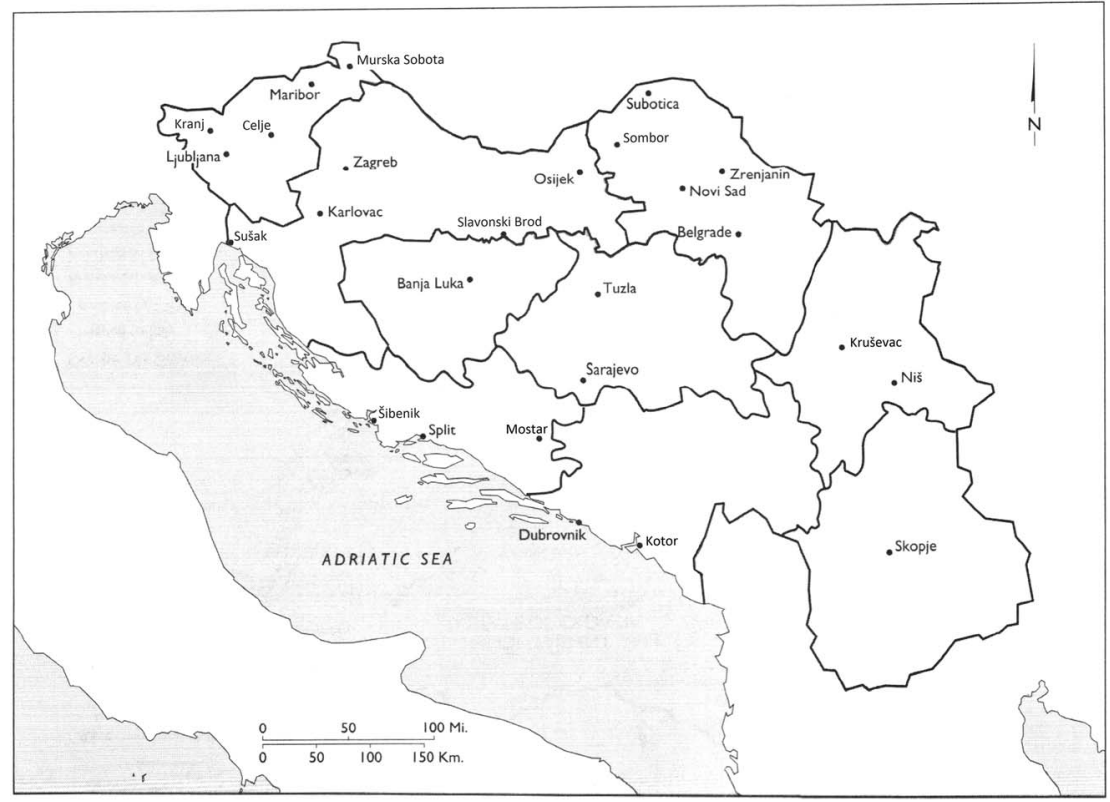

Figure I. Hostels for jobless workers in Yugoslavia at the end of the I930s.

Information from: Petrovic, Nezaposlenost, pp. 96-97; Mario Krmpotic, "Spisak radnickih skloništa i kubinja pri pojedinim ustanovama javne službe posredovanja rada" [List of Workers' Refuges and Kitchens Located at the Institutions of the Public Service for Job Intermediation], SA, I936, 4, pp. 4I-44; the map's revised background is taken from Ramet, The Three Yugoslavias, p. xxiii.

charitable or private initiatives. What occurred, in the context of the changes in Yugoslav social policy described above, was rather a "convergence of interests" between municipal and state authorities, with the aim of combating the pressing mass unemployment of those years.

The international context played a role not only in the development of a new public social policy in general terms, but also more specifically in the projects of the hostels. Analogous initiatives in some central European cities were actually examined and compared. For the Belgrade project, for example, two representatives, a man and a woman, were sent to Pest, Prague, Dresden, and Vienna, to collect information on local aid facilities and on how they operated. ${ }^{82}$ The creation of jobless workers' hostels all over Yugoslavia was thus the result of the interaction of such international, national, and local dynamics. On the eve of World War II there were twenty-six of them in total, spread throughout the country (see Figure I).

82. Their report can be found in IAB, FOND, box 58,30 November 1928. 
Table I. Hostel capacity at the beginning of 1936.

\begin{tabular}{lccc}
\hline City/Town & Total & Men & Women \\
\hline Belgrade & $408^{*}$ & 327 & 81 \\
Sušak & 150 & Men only & \\
Ljubljana & 163 & 125 & 38 \\
Split & $130^{* *}$ & 69 & 24 \\
Zagreb & 120 & Men only & \\
Novi Sad & 73 & 63 & 10 \\
Sarajevo & 70 & 60 & 10 \\
Banja Luka & 30 & 25 & 5 \\
Sombor & 30 & 23 & 7 \\
Osijek & 25 & 20 & 5 \\
Niš & 15 & Men only & 2 \\
Sl. Brod & 14 & 12 & 3 \\
Subotica & 13 & 10 & 2 \\
Mostar & 12 & 10 & \\
Kotor & 10 & Men only & \\
Dubrovnik & 150 (“boards”, not “beds”) & Men only & \\
\hline
\end{tabular}

*The number of beds was increased to 427 in 1937, and to 438 in March 1938; Vidaković, Zdravlje i socijalna pomoć, p. 373; IAB, Ninth Annual Report 1938, p. 4. **The hostel in Split included twenty-eight beds for apprentices, and a few more for other professional categories.

Sources: Krmpotić, "Spisak radničkih skloništa"; Ilija P. Perić, "Otvorenje Radničkog skloništa u Splitu” [Opening of the Workers' Hostel in Split], SA, I935, I I-I 2, pp. 202-203.

\section{RUNNING THE HOSTELS}

Most of the hostels were built and fitted out between 1932 and 1936 . Capacity could vary considerably, as could the general terms and conditions of admission. While in most circumstances an overnight stay had to be paid for, generally at the rate of 4 dinars per night (the rate in Ljubljana was 5 dinars), four hostels offered free shelter. In the smaller hostels, especially, the use of the facility was limited to between three and five nights; in some larger hostels there was no formal limit on how long one could stay.

Who was entitled to sleep in these hostels? Considering that in most facilities users had to pay, lodgers had to have at least some cash. Poverty, therefore, was not a valid reason for admission. After all, even the name of these institutions made it clear that they were not designed for "poor" people and "vagrants", for whom there existed, as mentioned, specific institutions.

This emerges even more clearly from the requirement stipulating (at least theoretically in some hostels, and certainly for those in the larger cities) that workers be registered for social insurance. ${ }^{83}$ It was not enough,

83. See, for example, in relation to Belgrade: IAB, "Rules", art. 2; to Zagreb: DAZ, SO, box 2, "Kučni red radničkog prenočišta na Zavrtnici u Zagrebu", s.d. [House Rules of the Workers' Hostel in Zagreb]; [hereafter, DAZ, "House Rules”], art. I. 
Table 2. Prices and maximum duration (if known) of overnight stays, 1936.

\begin{tabular}{lcc}
\hline City/Town & Price per night, in dinar & Maximum duration \\
\hline Belgrade & 4 & 7 nights (longer if free beds available) \\
Sušak & 4 & \\
Ljubljana & 5 & Unlimited \\
Split & 4 & Minimum 3 nights \\
Zagreb & 4 & Unlimited \\
Novi Sad & First three nights free, then & Unlimited \\
& 4 dinar & 3 nights (longer if free beds available) \\
Sarajevo & 3 & 3 nights (longer if free beds available) \\
Banja Luka & 3 & 3 nights \\
Sombor & 4 & 3 nights \\
Osijek & 4 & 5 nights \\
Niš & Free & 1 night (exceptionally 2) \\
Sl. Brod & 4.50 & 3 nights \\
Subotica & Free & 3 nights (longer if free beds available) \\
Mostar & 3 & 5 nights \\
Kotor & Free & \\
Dubrovnik & 2 & \\
\hline
\end{tabular}

*Actual average number of nights: in 1932-1933, men fewer than Io days, women fewer than is days (IAB, Fourth Annual Report 1933, p. I4); in 1937-1938, men Io days, women I9 days (IAB, Ninth Annual Report 1938, p. 7).

Source: Krmpotić, "Spisak radničkih skloništa”; Poslovnik, art. 3.

therefore, simply to be vaguely "unemployed". A potential occupant had to belong to one of the professional categories covered by the workers' insurance law, and to have paid insurance contributions. And this had to be proved by submitting appropriate documentation. Whoever knocked on the doors of these institutions needed to be in possession of at least some money and a valid insurance card.

It goes without saying that such restrictions excluded legions of "aspiring workers" who arrived in the big cities. These institutions were therefore open only to certain people, to the "elite" of the unemployed, so to speak. All in all, the former were "well-off" compared with "the large majority of miserable workers and farmers [who] continue to lack a roof". ${ }^{4}$ The intention was to "conceive of" unemployment through such rules, to define it, to limit it, and to establish a hierarchy among those looking for work. By doing so, a mini-elite among the unemployed were created, who managed, in spite of everything, to obtain a cot and a shower, at least for a few days.

The formalization of and internal hierarchy among the unemployed can also be traced in other analogous assistance initiatives. For example, the 


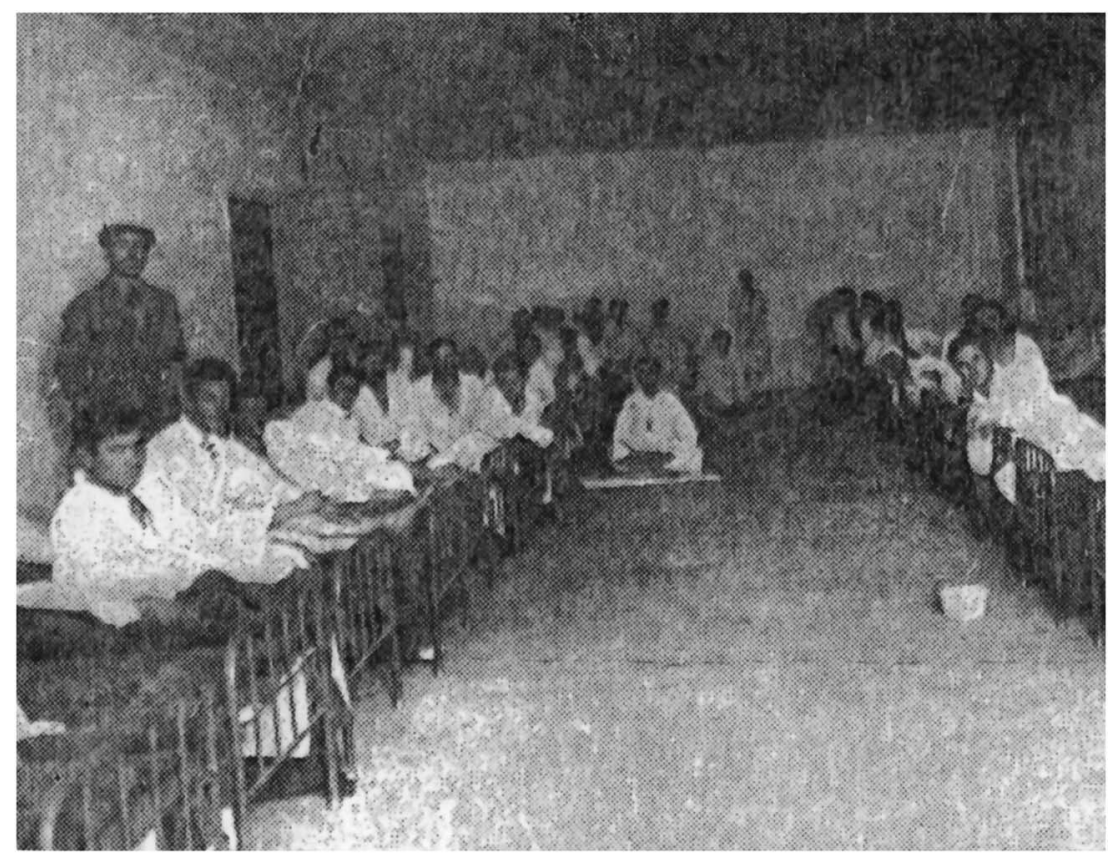

Figure 2. Sleeping room in the male workers' hostel in Belgrade.

Editorial Board, "Naše građevine", p. 43.

rules for train and ferry tickets for the unemployed are very precise and define a time limit since the applicant's previous occupation, the duration of their previous occupation, the probability of finding a job in the place of destination, and a series of other aspects. ${ }^{85}$ Similarly, the right to benefit from the soup kitchens for the unemployed also depended on one's working status, family situation, and a range of other factors. ${ }^{86} \mathrm{It}$ is even possible to observe how such rules were refined over time, usually becoming more restrictive.

85. See the related legal rules: "Pravilnik o povlašćenoj vožnji nezaposlenih radnika na držav. železnicama i brod. i Uputstva za njegovo izvršenje” [Rules for Discounted Tickets for Unemployed Workers Travelling on State Rail or State Ferries, and the Instructions for their Implementation], SA, I935, 3, pp. 9-10; "Uputstva za izvršenje 'Pravilnika o povlašćenoj vožnji nezaposlenih radnika" [Instructions for the Implementation of the "Rules for Discounted Tickets for Unemployed”], ibid., pp. ı-I I; "Pravilnik o povlašćenoj vožnji nezaposlenih radnika na Jadranskom moru i Skadarskom Jezeru i Uputstva za njegovo izvršenje” [Rules for Discounted Tickets for Unemployed Workers Travelling in the Adriatic Sea and on Lake Skadar, and the Instructions for their Implementation], ibid., pp. I I-I 2.

86. Mario Krmpotić, "Spisak radničkih skloništa i kuhinja pri pojedinim ustanovama javne službe posredovanja rada" [List of Workers' Refuges and Kitchens Located at the Institutions of the Public Service for Job Intermediation], $S A$, 1936, 4, pp. 4I-44. 
Internal distinctions and definition strategies also had a gender dimension: although there were two hostels only for women (in Belgrade and Ljubljana), ${ }^{87}$ many of the other hostels were designated exclusively for men, and in cases where both sexes were admitted there were always many fewer places for women than for men (see Table I). Certainly, there were some facilities provided especially for female workers, including breast-feeding working mothers, but the entire scheme, in general terms, was evidently designed primarily for men. Furthermore, gender discrimination was at the source of the system: the hostels were conceived first and foremost for insured workers, and the percentage of insured male workers was higher than the percentage of insured female workers. ${ }^{88}$ This necessarily resulted in women having more limited access to these institutions - not to mention the difficulty they faced in paying for the tickets in cash.

Even the 4 dinars charged at the majority of hostels was actually too much for most of the unemployed. In the mid-1930s 4 dinars represented roughly one-fifth of the average male daily wage. ${ }^{89}$ In Zagreb, complaints about this attracted the attention of the press, which explained why many workers preferred, at half the price, to opt for a bed in one of the crowded private dormitories on the outskirts of the city, where there was the further possibility of sharing the bed, and thus the cost. ${ }^{\circ}$ The hostel's managing board did consider the workers' request to reduce the price to 3 dinars, but in the end they decided against it. ${ }^{91}$ In Belgrade, too, where initially one had to pay 5 dinars, ${ }^{92}$ later (in 1935) reduced to $4,{ }^{93}$ the issue was constantly discussed. It was noted that many construction workers ended up sleeping at the construction site. Nonetheless, the principle that "everyone pays" (with the exception of children) was firmly maintained, as was the idea that anything less than 4 dinars was unthinkable. ${ }^{94}$

It was not always the workers who paid: from the beginning, the system was conceived in such way that it envisaged "coupons" being purchased and distributed by local labour offices, workers' chambers, and

87. Those same cities also had hostels only for men.

88. Calic, Sozialgeschichte Serbiens, pp. $258-262$.

89. In 1930 the average nominal daily male wage was 26.56 dinars; by 1935 it had fallen to 21.65 dinars. There were notable differences in any case depending on sex and age, as well as regional origin, between the kingdom's poorer south and east, and the north and west; Calic, Sozialgeschichte Serbiens, pp. $38 \mathrm{I}-385$.

90. "I četiri dinara je previše!” [Even Four Dinars Are Too Much!], Novosti, I I July i 933.

91. DAZ, "Final Report 1937", p. 6.

92. IAB, FOND, Prvi godišnii izveštaj [First Annual Report] (Belgrade, I930), p. I6.

93. [Anon.], "Izveštaj Fonda za stvaranje i održavanje radničkih ustanova u Beogradu o radu u I934/35 budž god" [Report of the Fund for Establishing and Maintaining Worker Institutions in Belgrade on Activities During the Budget Year 1934-1935], SA, 1935, 7-8, p. I38.

94. IAB, Fourth Annual Report 1933, pp. I0-I I. 
other worker or humanitarian organizations. In the case of Belgrade this related to a low percentage of overnight stays, some of them offered by the labour office (few during the i930s, and none at all by the end of the decade), others were paid through aid or charitable associations (increasingly so during the I930s). In fact, in 1932-193390 per cent of hostel users paid out of their own pockets; between 1935 and 1938 the figure was between 84 and 88 per cent. ${ }^{95}$ The situation was different in Zagreb, where initially (1934-1935) the labour office paid for 35 per cent of overnight stays, a figure that rose to 53 per cent the following year. Although this assistance was later to diminish, in 1936-1937 almost half of overnight stays were still paid for by the labour office and workers' chamber..$^{96}$

Furthermore, for every rule there was an exception - several, in the cases investigated here. In the men's hostel in Belgrade, for instance, one could be hosted for free. This was allowed, however, only under special circumstances, such as if one had just arrived in the city and been unable to register with the institutions that dispensed the "coupons". By submitting worker documentation recording personal data and previous employment the newly arrived could be admitted, provided there were free beds, for at the most one night. ${ }^{97}$ This represented an extremely low proportion of the total number of overnight stays, around 4 per cent at the beginning of the r 930 s and 5 per cent at the end of the decade..$^{8}$

This was not the only exception that was made with regard to admission: even if the hostel in Zagreb was designated "above all for travelling unemployed persons", ${ }^{99}$ any remaining beds could be occupied by "local" workers (the duration of whose stay was not limited), while reports also mentioned "permanent guests". ${ }^{\circ 0}$ And although the hostel was supposed to give refuge to "in theory, unemployed people", if beds remained unoccupied they could also be assigned to "workers with a job", and this is why such workers paid a few dinars more. ${ }^{\text {IOI }}$ After all, these facilities

95. Ibid., p. I 2; IAB, Ninth Annual Report 1938, p. 6.

96. DAZ, SO, box 2, "Iskaz o broju prenoćenja od I travnja I934 do 3 I ožujka I935” [Register of the Overnight Stays Between I April 1934 and 3I March 1935], 25 October 1935; ibid., "Izvještaj o poslovanju u Gradskom radničkom prenoćištu u Zagrebu u budžetskoj godini 1935/36" [Report on the Activities of the City Workers' Hostel in Zagreb During the Budget Year $1935 / 36$ ], no pagination; DAZ, "Final Report 1937", p. 6.

97. IAB, "Rules", art. 2.

98. IAB, Fourth Annual Report 1933, pp. I0, I2; IAB, Ninth Annual Report 1938, pp. 6-7.

99. DAZ, "House Rules", art. 2. The male hostel in Ljubljana was similarly designated primarily for "unemployed persons in transit", as were all the minor hostels, such as those in Mostar and Tuzla; Editorial Board, "Naše građevine", p. 204.

I00. DAZ, "Final Report I937", p. 2.

ıо . IAB, "Rules", art. 2. 
Table 3. Overall number of overnight stays in Belgrade's male and female workers' hostels.

\begin{tabular}{lc}
\hline Year & No. of overnight stays \\
\hline February/March 1930* & 27,332 \\
$1930-1931$ & 96,244 \\
$1931-1932$ & 124,223 \\
$1932-1933$ & 112,831 \\
$1933-1934$ & $226,835^{* *}$ \\
$1934-1935$ & 123,061 \\
$1935-1936$ & 126,973 \\
$1936-1937$ & 141,730 \\
\hline
\end{tabular}

*The data for the budget year I929-1930 refer only to these two months as the hostels did not open until the beginning of February i930; from the next line on the data refer to the entire budget year (from April to March of the next year). **The available sources do not allow one to separate out the figures for these two budget years.

Sources: IAB, FOND, box 59, "Prvi godišnji izveštaj", p. I6; IAB, Fourth Annual Report 1933, p. 9; IAB, Ninth Annual Report 1938, pp. 4-5; Vidaković, Zdravlje $i$ socijalna pomoć, p. $37 \mathrm{I}$.

aimed to have as many beds as possible occupied; whether overnight stays were paid through the "coupons", directly by jobless workers, or by workers with a job was of secondary importance.

Summing up all the results of these initiatives one can conclude that, despite having to purchase tickets (though in some locations the aid provided was substantial), workers made widespread use of these hostels. Even though no overall data covering all hostels are available, the available documentation is sufficient to enable us to understand how those structures operated. In the Belgrade hostels, for instance, in 1937-1938 almost i I 6,000 overnight stays were recorded in the male hostel and more than 25,700 in the female, ${ }^{102}$ with a total, during eight years of activity (1930-1938), of 979,229 overnight stays. ${ }^{103}$

The figures relating to the other hostels are quite different, due to their smaller size and differing socio-economic contexts. Nonetheless, even in the case of the small hostel in Zagreb, 92,932 overnight stays were recorded for the first four years (1933-1937) of activity. ${ }^{\text {104 }}$ Yugoslav's other hostels must also have operated at full capacity, given that in its budget for 1939 Split envisaged an income of 97,000 dinars from paying

102. IAB, Ninth Annual Report 1938, p. 5 .

103. Ibid., p. 8.

I04. DAZ, "Final Report 1937", p. 4. 
Table 4. Overall number of overnight stays in Zagreb's male workers' bostel.

\begin{tabular}{lr}
\hline Year & Total \\
\hline $1933^{*}$ & 14,554 \\
$1934-1935$ & 28,253 \\
$1935-1936$ & 27,223 \\
$1936-1937$ & 22,902 \\
\hline
\end{tabular}

* The data for the first three months of 1934 are unavailable.

Sources: "I 4.554 radnika"; DAZ, SO, box 2, "Iskaz o broju prenoćenja"; DAZ, SO, box 2, "Izvještaj o radu i poslovanju u Gradskom radničkom prenoćištu u Zagrebu, Heinzelova ulica 78 u budžetskoj godini i935/36”, p. 2; DAZ, SO, box 2, "Final Report 1937", p. 4.

guests, and the other hostels too assumed full occupancy. ${ }^{\text {IOS }}$ The general impression is that the system worked quite well, and a considerable number of jobless workers in Yugoslavia were able to take advantage of it.

\section{CONCLUSION}

In his address to inaugurate a new building that included a workers' hostel, a member of the Central Agency stated that: "[i]nvested in this useful and attractive edifice is money derived exclusively from employers' and workers' contributions, and it is therefore a workers' bouse" ${ }^{106}$ The financing issue was one initial aspect that distinguished these the new social policies from the assistance previously provided to the poor and to workers: the workers' hostels were not the result of private charity, nor solely of municipal initiatives; they were the result of an interaction between local and state public organs within the framework of an emerging welfare system. As I have shown by analysing the funding of the workers' hostels, those hostels were built and maintained exclusively using public money.

While many aspects of the nascent Yugoslav welfare policy in the interwar period are already known, taking a more micro-analytical approach can contribute not only to revealing under-researched aspects, such as social policies towards jobless workers; it can also shed more light on the changes that occurred in state and municipal social policy as well as in political culture. External factors, such as international obligations and the influence of the International Labour Organization, together with domestic developments, including political and economic reforms, the affirmation of state interventionism, the local effects of the world

105. See the "budgets" for the hostels in Sarajevo and in Novi Sad, SA, I938, I0-I2, pp. 322-326.

I06. [Anon.], "Svečano otvorenje" (italics mine). 
economic crisis, and, last but not least, the drastic growth of unemployment, promoted new approaches towards social care and unemployment in particular. It is therefore possible to maintain that, in spite of all the hesitation and difficulties relating to Yugoslav social policy during this period, especially regarding the unemployed, expensive structures were established in order to offer, at least for some, temporary refuge.

The history of the workers' hostels also gives an opportunity for further insights into the emergence of new concepts of unemployment and into the nature of the facilities for the unemployed, as well as into the ways they distinguished themselves from traditional, philanthropic poverty relief. In this process new definitions and boundaries were elaborated: the rules that regulated access to these hostels shaped in a normative way various sub-types of the unemployed: from the "elite", the relatively well-off workers able to pay for their stay themselves; the "second class", jobless workers who received coupons for free, because they satisfied all the formal requirements; and the "third class", the excluded ones, who were not registered for social insurance and were too poor to purchase a ticket that would have allowed them to stay.

Apart from all the limitations of the system, from a theoretical as well as cultural and legal point of view a novelty was introduced: the unemployed acquired a proper juridical as well as social profile, and for some of them this was linked to new privileges. A "right" was taking form, which some of the unemployed could now claim. Far from being charity, this kind of aid was a welcome novelty for some Yugoslav (jobless) workers.

At the same time, the exclusion mechanisms gained in clarity: those who did not belong to these socio-professional categories were simply not admitted, and relegated to poverty refuges or other institutions. The analysis of the general legal framework, and especially of the specific rules and regulations of the hostels, has shown that these further emphasized the distance between insured and uninsured workers and between men and women. Being at the crossroads of poor relief and provision for workers, these hostels allow a precise observation of the boundaries between these two spheres. What has emerged is that these institutions were not simply for persons looking for work, but - as the very name of the hostels made clear - for "jobless workers".

\author{
TRANSLATED ABSTRACTS \\ FRENCH - GERMAN - SPANISH
}

Stefano Petrungaro. Foyers d'hébergement pour travailleurs an chômage dans la Yougoslavie de l'entre-denx-guerres (I92 I-I94I).

Cet article analyse la création d'un réseau de foyers d'hébergement destinés aux travailleurs chômeurs en Yougoslavie entre les deux guerres mondiales. L'analyse 
étudie l'arrière-plan juridique, politique et institutionnel de ces foyers d'hébergement, et comment ils furent conçus et financés. En considérant le développement d'une nouvelle politique sociale publique du point de vue des chômeurs, l'article vise à examiner la nature, les objectifs et particulièrement les limites d'une prévoyance yougoslave moderne pour les travailleurs, c'est-à-dire ses stratégies et ses pratiques d'inclusion et d'exclusion sociales. L'article montre qu'une idée moderne du chômage émergea progressivement. Ces foyers d'hébergement ne firent pas partie d'une politique traditionnelle en matière de pauvreté, mais ils furent l'expression d'une forme de politique sociale nouvelle et plus moderne. L'article montre en outre comment des différences et des distances sociales entre des personnes "qui ne travaillent pas" furent créees, et l'effet concret qu'elles eurent sur le fonctionnement de ces institutions.

Traduction: Christine Plard

Stefano Petrungaro. Wohnheime für erwerbslose Arbeiter im Jugoslawien der Zwischenkriegsjabre (I92 I-I94I).

Dieser Artikel untersucht den Aufbau eines Netzwerks von Wohnheimen für erwerbslose Arbeiter in Jugoslawien zwischen den beiden Weltkriegen. Die Untersuchung fragt nach dem rechtlichen, politischen und institutionellen Hintergrund dieser Wohnheime und danach, wie sie konzipiert und finanziert wurden. Indem die Entwicklung einer neuen öffentlichen Wohlfahrtspolitik aus der Perspektive der Erwerbslosen betrachtet wird, wird in dem Artikel versucht, das Wesen, die Ziele und vor allem auch die Grenzen der modernen jugoslawischen Arbeiterwohlfahrt zu untersuchen, d.h. deren Strategien und Praxen sozialer Inklusion und Exklusion. Der Artikel zeigt, wie es allmählich zur Herausbildung einer modernen Vorstellung von Erwerbslosigkeit kam. Die Wohnheime waren kein Bestandteil einer traditionellen Armenfürsorge mehr, sondern Ausdruck einer neuen, moderneren Form der Wohlfahrtspolitik. Der Artikel legt darüber hinaus auch dar, wie unter "nicht arbeitenden" Menschen neue soziale Differenzen und Distanzen geschaffen wurden und welche konkreten Folgen solche Unterscheidungen für die Funktionsweise dieser Einrichtungen hatten.

Übersetzung: Max Henninger

Stefano Petrungaro. Albergues para trabajadores desempleados durante la época de entreguerras en Yugoslavia (I92 I-I94I).

Este artículo analiza el establecimiento de una red de albergues destinados a los trabajadores en paro en Yugoslavia en el periodo que corre entre las dos guerras mundiales. El análisis investiga el trasfondo legal, político e institucional de este tipo de albergues, el proceso por el que fueron concebidos y la forma en que fueron financiados. Prestando atención al desarrollo de un nuevo tipo de política social pública desde la perspectiva del desempleado, el artículo trata de examinar la naturaleza, los objetivos y, especialmente, los límites de prestaciones modernas para los trabajadores en Yugoslavia, específicamente sus estrategias y prácticas de 
inclusión y exclusión social. El artículo muestra la emergencia de forma gradual de una idea moderna de desempleo. Este tipo de albergues no fueron parte de una política tradicional de asistencia a los pobres, sino que fueron la expresión de una nueva y más moderna forma de política social. El texto, además, muestra cómo se creaban nuevas diferencias y distancias sociales entre personas "no trabajadoras", y el impacto concreto que tuvieron sobre el funcionamiento de este tipo de instituciones.

Traducción: Vicent Sanz Rozalén 